\title{
Influence of skin folding types on the efficiency of feed in Groznensky sheep
}

\author{
Y.A. Yuldashbaev, A.R. Demurova
}

${ }^{1}$ Russian State Agrarian University -Moscow agricultural Academy after K.A. Timiryazev, Moscow 127550;

${ }^{2}$ Gorsky State Agrarian University, 362040, RNO-Alania, Vladikavkaz, Kirov Street, 37;

Corresponding e-mail: texmen2@mail.ru

Journal of Livestock Science (ISSN online 2277-6214) 12: 255-261

Received on 9/6/21; Accepted on 27/7/21; Published on 10/8/21

doi. 10.33259/JLivestSci.2021.255-261

\begin{abstract}
In sheep husbandry, as in other branches of animal husbandry, emphasis is often given on study of the consumption and use of feed by sheep. The present study was aimed to determine the level of transformation of feed into products (feed conversion) by young animals of various types of skin folds economics of feed with respect to increase in live weight and wool. The study was carried out in the period from 2016 to 2019, on sheep of the Grozny breed, in the Limited Liability Company (LLC) Plemzvod "Chervlennye Buruny" of the Nogai region of the Republic of Dagestan, Russia. It was found that young animals with an insufficient supply of skin spend on $1 \mathrm{~kg}$ of live weight gain - $6.80-9.68 \mathrm{ECU}$ (energy feed unit (ECU) is taken $10 \mathrm{MJ}$ of exchange energy), and peers with a satisfactory and increased supply of skin, respectively $8.00-10.91$ and 9.77-11.87 ECU. Average daily gain in live weight in young animals with insufficient skin supply is $1.9-29.6 \%$ higher than in peers of other types. The growth of wool in pure fiber on an area of $100 \mathrm{~cm}^{2}$ is higher in young animals with a satisfactory supply of skin, which surpassed their peers with an insufficient supply of skin by 2.2 - 8.0 and with an increased supply of skin - by 2.0 $7.8 \%$. Differentiated determination of feed consumption per 1 kilogram of live weight gain and pure wool gain showed that animals with a satisfactory skin supply for wool growth consume the least amount of feed at average costs for live weight gain.
\end{abstract}

Key words: lamb; rams; type of skin folding; live weight; average daily gain; economics of feed conversion into live weight and wool. 


\section{Introduction}

The selection of animals with high feed conversion ratio is critical to the efficiency of the sheep breeding industry. In sheep breeding, as in other branches of animal husbandry, much attention is paid to the study of the consumption and use of feed by sheep, depending on the type of animals (Gogaev et al., 2016; Gogaev et al., 2017; Gogaev et al., 2018a; Gogaev et al., 2018b; Gogaev et al., 2019a; Gogaev et al., 2020a). In livestock practice, breeding animals with high feed conversion rate increases economic efficiency. It is known that animals of certain breeds, under equal conditions of feeding and management, use feed differently, since feed costs per unit of gain in live weight and wool are different and the efficiency of sheep development is not the same (Gogaev et al., 2015; Gogaev et al., 2019b; Gogaev et al., 2019c; Gogaev et al., 2020b, Kessaev et al., 2011; Kessaev et al., 2013; Kessaev et al., 2017). In this regard, we were faced with the task of determining the level of transformation of feed into products by young animals of various types in the experiment on economics of feed with respect to increase in live weight and wool.

\section{Material and methods}

The experiment was carried out from 2016 to 2019 in the Limited Liability Company (LLC) "Plemzvod" Chervlennye Buruny "of the Nogai district of the Republic of Dagestan, located $44^{\circ} 10^{\prime} 41^{\prime \prime}$ north latitude, $45^{\circ} 37^{\prime}$ 24 "east longitude and 52 meters above sea level.

To study the effect of the type of skin folding on the efficiency of feed use at the age of seven months, 9 groups of young Grozny breed were formed:

- Group I - females with insufficient skin supply (type C-);

- Group II - females with a satisfactory supply of skin (type C);

- Group III - females with an increased supply of skin (type C +);

- IV group - males with insufficient skin supply (type C-);

- Group V - males with a satisfactory supply of skin (type C);

- Group VI - males with an increased supply of skin (type C +);

- VII group - castrated males with insufficient skin supply (type C-);

- Group VIII - castrated males with a satisfactory supply of skin (type C);

- Group IX - castrated males with an increased supply of skin (type C +).

The trial period lasted 60 days.

To take into account the increase in wool, before setting the lambs for the experiment, on an area of 100 $\mathrm{cm} 2(10 \times 10 \mathrm{~cm})$, wool was sheared on the left side of 5 heads from each group. At the end of the experiment, the wool that grew in this area was sheared and the following were determined: the growth of wool in the original and in pure fiber; yield of pure wool in\%; natural and true coat length; fineness of wool.

\section{Results}

The feed used in the experiment, as can be seen from the data in Table 1, was of average quality in terms of nutritional value, the moisture content in the silage was 70 , in the beets $-88 \%$, the rest of the feed also had normal moisture.

Table 1 - Nutritional value of forages used in the experiment

\begin{tabular}{|l|l|l|l|l|l|}
\hline Feed Type & $\begin{array}{l}\text { EKE (Energy } \\
\text { feed unit) }\end{array}$ & $\begin{array}{l}\text { Digestible } \\
\text { protein, g }\end{array}$ & $\begin{array}{l}\mathrm{Ca} \\
\mathrm{g}\end{array}$ & $\begin{array}{l}\mathrm{P} \\
\mathrm{g}\end{array}$ & $\begin{array}{l}\text { Carotene } \\
\mathrm{mg}\end{array}$ \\
\hline Sudanese hay & 0.50 & 67.0 & 5.40 & 2.88 & 0.258 \\
\hline Corn silage & 0.24 & 15.0 & 1.95 & 0.96 & 0.108 \\
\hline Fodder beets & 0.11 & 10.0 & 0.54 & 0.40 & - \\
\hline Oats & 1.0 & 80.0 & 2.20 & 3.06 & - \\
\hline Sunflower cake & 1.15 & 357.0 & 3.99 & 9.40 & - \\
\hline
\end{tabular}

When feeding the experimental lambs, they adhered to the approximate rations adopted on the farm (Tables $2,3)$. From the data presented, it can be seen that the eaten food of females with insufficient skin supply contained $815 \mathrm{ECU}$ and $93.2 \mathrm{~g}$ of digestible protein, or $1.2-6.1 \%$ less than in females with a satisfactory and increased skin supply. Approximately the same picture was observed for the food eaten by castrated males. Males with a 
satisfactory skin reserve ate $1.4 \%$ more food than peers with an increased skin reserve, and males with insufficient skin reserves, as well as females and castrated males, ate the least amount of food.

Similar results were obtained in studies by Kolosov (2012), who wrote that non-folding animals eat the least amount of food. Nezhlukchenko et al (2018), according to which the bright Ascanian breeds of the "C +" type eat the hay of the Sudanese, more than the multi-fold ones. Here, apparently, the direction of the productivity of the experimental sheep played a role. No definite regularity was found in the consumption of succulent forages. So, for females, the eatability of beets was higher in individuals with an insufficient supply of skin, silage, on the contrary, in individuals with an increased supply of skin, in non-castrated males the data on the eatability of beets were higher in animals with a satisfactory supply of skin, and the eatability of silage was higher in individuals with an increased supply of skin, which surpassed their peers in this indicator.

The concentrated feed was completely consumed by all animals. In the experiment, animals of different types of folding had different increments and payment for food, which can be seen from the data in Table 4. The difference was 19.1-29.6\%. Animals with a satisfactory skin reserve (groups II, IV, and VIII) occupied an average position for this indicator.

Table 2- Nutritional value and feed intake of the daily ration of experimental young animals

\begin{tabular}{|c|c|c|c|}
\hline \multirow{2}{*}{ Group } & \multicolumn{3}{|c|}{ Indicator } \\
\cline { 2 - 3 } & \multicolumn{2}{|c|}{ Feed eaten } & Eaten EKE feed, \\
& EKE & Digestible protein & \\
\hline I & 815 & 93.2 & 78.8 \\
\hline II & 825 & 94.6 & 77.5 \\
\hline III & 865 & 98.6 & 81.4 \\
\hline IV & 874 & 102.4 & 76.2 \\
\hline V & 919 & 106.5 & 78.5 \\
\hline VI & 906 & 105.9 & 79.4 \\
\hline VII & 725 & 84.8 & 75.6 \\
\hline VIII & 762 & 87.6 & 73.9 \\
\hline IX & 779 & 90.2 & 76.5 \\
\hline
\end{tabular}

The consumption of feed in ECE per unit of gain, as can be seen from this table, is the highest in animals of groups III, VI and IX, compared with an insufficient supply of skin for females by $33.5 \%$, for non-castrated males $30.4 \%$ and for castrated males $-17.7 \%$, about the same difference in consumption of digested protein. Our data on feed consumption per kilogram of gain are consistent with the data of Aboneeva et al (1997) and Bolotov (2011).

When comparing the data on payment for food, it was found that the best indicators were characterized by noncastrated males (IV, V and VI groups), the least by castrated males (VII, VIII and IX groups). The superiority of non-castrated individuals for this indicator over castrated peers averaged 37\%. This pattern of payment for feed in increments must be taken into account when organizing the feeding and fattening of young animals. A significant difference was also noted in the growth of wool in lambs of different types of skin folds on an area of $100 \mathrm{~cm}^{2}$. The data in Table 4 show that the largest amount of wool in the original was obtained from animals with an increased skin supply (groups III, VI and IX), the smallest - from animals with an insufficient skin supply (groups I, IV and VII). In pure fiber, more wool was obtained from individuals with a satisfactory supply of skin (groups II, V and VIII).

In terms of the percentage of pure wool yield, animals with an insufficient skin supply (groups I, IV, and VII) outnumbered individuals with a satisfactory skin supply (groups II, V, and VIII) by an average of $0.37-6.05$ and animals with an insufficient skin supply (I, IV and VII groups) - by $7.41-13.46 \%$. Approximately the same data were obtained on the yield of pure wool for the entire experimental young stock when it was determined individually.

Wool that grew during the experimental period in young animals of different types of skin folds had different lengths. Animals with an insufficient skin supply (groups I, IV, and VII), according to this indicator, outperformed individuals with a satisfactory skin supply (groups II, V and VIII) by $8.1-19.2 \%$, and animals with an increased skin supply (III, VI and IX groups) - by $17.7-40.9 \%$. The thickness of wool in all groups ranges from 18.47 - 21.39 microns (70 - 64 qualities). 
Table 3 - Daily rations and feed intake by experimental young animals for the experimental period (60 days)

\begin{tabular}{|c|c|c|c|c|c|c|c|c|c|c|c|}
\hline \multirow{2}{*}{ Feed Type } & \multirow[t]{2}{*}{ Indicator } & \multirow[t]{2}{*}{ Ed. Id. } & \multicolumn{9}{|c|}{ Group } \\
\hline & & & I & II & III & IV & $\mathrm{V}$ & VI & VII & VIII & IX \\
\hline \multirow{3}{*}{$\begin{array}{c}\text { Sudanese } \\
\text { hay }\end{array}$} & given & $\mathrm{g}$ & 411 & 430 & 430 & 402 & 414 & 402 & 408 & 425 & 421 \\
\hline & eaten & $\mathrm{g}$ & 217 & 239 & 275 & 178 & 188 & 211 & 213 & 190 & 239 \\
\hline & Palatability & $\%$ & 52.80 & 55.98 & 63.26 & 44.28 & 45.42 & 52.49 & 52.21 & 44.71 & 56.77 \\
\hline \multirow{3}{*}{ Fodder beats } & given & $\mathrm{g}$ & 4623 & 4902 & 4910 & 5247 & 5415 & 5214 & 3955 & 4391 & 4286 \\
\hline & eaten & $\mathrm{g}$ & 4086 & 4154 & 4300 & 4485 & 4662 & 4436 & 3281 & 3678 & 3576 \\
\hline & Palatability & $\%$ & 88.38 & 84.74 & 87.58 & 85.48 & 86.09 & 85.08 & 82.96 & 83.60 & 83.44 \\
\hline \multirow{3}{*}{ Oats } & given & $\mathrm{g}$ & 83 & 83 & 83 & 83 & 108 & 107 & 108 & 85 & 87 \\
\hline & eaten & $\mathrm{g}$ & 83 & 83 & 83 & 83 & 108 & 107 & 108 & 85 & 87 \\
\hline & Palatability & $\%$ & 100 & 100 & 100 & 100 & 100 & 100 & 100 & 100 & 100 \\
\hline \multirow{3}{*}{$\begin{array}{l}\text { Sunflower } \\
\text { cake }\end{array}$} & given & $\mathrm{g}$ & 71 & 70 & 70 & 91 & 91 & 91 & 69 & 71 & 71 \\
\hline & eaten & $\mathrm{g}$ & 71 & 70 & 70 & 91 & 91 & 91 & 69 & 71 & 71 \\
\hline & Palatability & $\%$ & 100 & 100 & 100 & 100 & 100 & 100 & 100 & 100 & 100 \\
\hline \multirow{3}{*}{ Corn silage } & given & $\mathrm{g}$ & 650 & 609 & 600 & 655 & 655 & 639 & 643 & 695 & 703 \\
\hline & eaten & $\mathrm{g}$ & 383 & 354 & 376 & 393 & 416 & 415 & 382 & 392 & 405 \\
\hline & Palatability & $\%$ & 58.92 & 58.13 & 62.67 & 60.00 & 63.51 & 64.95 & 59.41 & 56.55 & 57.61 \\
\hline
\end{tabular}

Table 4 - Payment for feed by products of experimental young animals

\begin{tabular}{|c|c|c|c|c|c|c|c|c|c|c|}
\hline \multirow{2}{*}{\multicolumn{2}{|c|}{ Indicator }} & \multicolumn{9}{|c|}{ Group } \\
\hline & & I & II & III & IV & $\mathrm{V}$ & VI & VII & VIII & IX \\
\hline \multicolumn{11}{|c|}{ Payment for feed by gain in live weight } \\
\hline \multicolumn{2}{|l|}{ Number of heads } & 17 & 15 & 13 & 14 & 15 & 15 & 11 & 10 & 10 \\
\hline \multicolumn{2}{|c|}{ Live weight at the start of experiment, $\mathrm{kg}$} & 28.65 & 29.93 & 27.69 & 30.07 & 32.43 & 30.17 & 28.96 & 26.30 & 27.30 \\
\hline \multicolumn{2}{|c|}{ Live weight at the end of experiment, $\mathrm{kg}$} & 35.10 & 35.03 & 32.23 & 37.48 & 39.99 & 36.41 & 33.09 & 30.14 & 30.91 \\
\hline \multicolumn{2}{|c|}{ Total gain, $\mathrm{kg}$} & 6.45 & 5.10 & 4.54 & 7.71 & 7.56 & 6.24 & 4.13 & 3.84 & 3.61 \\
\hline \multicolumn{2}{|l|}{ Average daily gain, $g$} & 107.6 & 84.9 & 75.6 & 126.5 & 126.0 & 104.1 & 74.9 & 69.8 & 65.6 \\
\hline \multirow[t]{2}{*}{ Feed consumed/ kg gain, kg } & EKE & 7.60 & 9.73 & 11.43 & 6.80 & 8.00 & 9.77 & 9.68 & 10.91 & 11.87 \\
\hline & per. protein & 0.863 & 1.114 & 1.304 & 0.797 & 0.928 & 1.017 & 1.132 & 1.225 & 1.373 \\
\hline \multicolumn{11}{|c|}{ The growth of wool in the experimental young stock per $100 \mathrm{~cm} 2$} \\
\hline \multicolumn{2}{|l|}{ Number of heads } & 5 & 5 & 5 & 5 & 5 & 5 & 5 & 5 & 5 \\
\hline \multicolumn{2}{|c|}{ growth of wool in the original/ head, g } & 8.188 & 8.960 & 10.526 & 8.442 & 8.820 & 8.938 & 6.410 & 7.280 & 8.02 \\
\hline \multicolumn{2}{|c|}{ Wool growth in pure fiber per head, $g$} & 5.700 & 6.200 & 5.970 & 6.696 & 5.820 & 5.368 & 4.667 & 4.860 & 4.760 \\
\hline \multicolumn{2}{|c|}{ Yield percentage of pure wool } & 69.62 & 69.25 & 56.69 & 67.47 & 66.00 & 60.06 & 72.81 & 66.76 & 59.35 \\
\hline \multirow{2}{*}{$\begin{array}{l}\text { length of the wool grown over } \\
\text { the period of the experiment, } \mathrm{cm}\end{array}$} & natural & 2.02 & 1.86 & 1.96 & 2.18 & 1.74 & 1.46 & 1.90 & 1.67 & 1.47 \\
\hline & true & 2.79 & 2.58 & 1.98 & 2.79 & 2.33 & 2.06 & 2.45 & 2.20 & 2.08 \\
\hline
\end{tabular}


In order to compare the consumption of feed by sheep separately for wool and growth, we used the standards according to which the cost of feed by a sheep for the production of a unit of production is distributed as follows: $40 \%$ for an increase in live weight and $60 \%$ for wool, while it should be borne in mind that these calculations are conditional.

The data on the gain and feed consumption for the gain in live weight and the growth of wool were taken from those actually available for the experimental period. When calculating wool productivity, we used the amount of wool on an area of $100 \mathrm{~cm} 2$ and the conditional area of sheepskin, by means of which we obtained an increase in wool over the entire area of the skin. The feed costs per unit of production calculated according to the abovementioned norms, are presented in Table 5. From the data in the table, it can be seen that, regardless of gender, in all animals, feed consumption per $1 \mathrm{~kg}$ of live weight gain increases with increasing skin folding. In the eaten food, the difference between individuals with an insufficient supply of skin and individuals with an increased supply of skin in feed consumption per $1 \mathrm{~kg}$ of gain was: for females - $1.54 \mathrm{ECU}$, for males - 0.76 ECU, for castrated males - 0 , 89 ECU, which is 33.7, 21.8 and 18.7 percent, respectively, approximately the same distribution is observed in the given feed.

When analyzing the data on feed costs per $\mathrm{kg}$ of pure wool gain, it can be seen that females with a satisfactory supply of skin consumed the smallest amount of them, which consumed 76.4 ECU in the eaten feed, and individuals with an insufficient and increased supply of skin spent respectively 8.5 and $19.4 \%$ more.

In non-castrated and castrated males, the smallest feed consumption per kilogram of pure wool gain is observed in animals with insufficient skin supply, and peers with a satisfactory and increased skin supply exceeded them in the amount of food eaten, respectively, for non-castrated males - by 1.5 and $16.7 \%$, castrated males -1.9 and $6.0 \%$.

When comparing feed consumption for live weight gain and wool gain in the context of sex groups, it can be noted that per unit of gain in live weight, the least food consumption was in non-castrated males, the highest in castrated males, females occupied an average position. In terms of feed consumption for the growth of pure wool, female and castrated males had approximately the same results, and in non-castrated males these data exceeded those of females and castrated males by $3.8-15.0 \%$. This, apparently, is due to the higher fat content in non-castrated males, which consumes a certain amount of food.

Table 5 - Feed consumption per kg of increase in live weight and wool of experimental young animals

\begin{tabular}{|c|c|c|c|c|c|c|}
\hline \multirow{3}{*}{ Group } & \multicolumn{5}{|c|}{ Lost EKE } \\
\cline { 2 - 7 } & \multicolumn{3}{|c|}{ in given feed } & \multicolumn{3}{c|}{ in the eaten feed } \\
\cline { 2 - 7 } & Total & $\begin{array}{l}\text { per kg gain } \\
\text { w.m. }\end{array}$ & $\begin{array}{l}\text { per kg of } \\
\text { wool growth }\end{array}$ & Total & $\begin{array}{l}\text { per kg gain } \\
\text { w.m }\end{array}$ & $\begin{array}{l}\text { per kg of wool } \\
\text { growth. }\end{array}$ \\
\hline I & 62.06 & 3.85 & 105.3 & 48.90 & 3.03 & 82.9 \\
\hline II & 63.87 & 5.01 & 98.6 & 49.50 & 3.88 & 76.4 \\
\hline III & 63.76 & 5.62 & 112.0 & 51.90 & 4.57 & 91.2 \\
\hline IV & 68.82 & 3.57 & 112.9 & 52.44 & 2.72 & 86.0 \\
\hline V & 70.24 & 3.72 & 111.2 & 55.14 & 2.92 & 87.3 \\
\hline VI & 68.46 & 4.39 & 126.7 & 54.36 & 3.48 & 100.4 \\
\hline VII & 52.75 & 5.11 & 108.5 & 39.88 & 3.86 & 82.1 \\
\hline VIII & 56.71 & 5.91 & 113.4 & 41.91 & 4.56 & 83.8 \\
\hline IX & 56.00 & 6.21 & 113.8 & 42.84 & 4.75 & 87.0 \\
\hline
\end{tabular}

\section{Discussion}

Countries with developed fine-wool sheep breeding currently prefer merino with relatively smooth skin, different from their predecessors, bred earlier. The practice of sheep breeding shows that an increased supply of skin contributes to the formation of more folds, which makes it difficult to shear the sheep and increases the amount of labor expended. The increased skin wrinkling also contributes to an increase in the shearing of dirty wool, due to the greater amount of grease, while the amount of washed fiber does not significantly increase. The hopelessness of sheep with an increased supply of skin is obvious, since these individuals have a looser constitution, which reduces the adaptive qualities of animals and, accordingly, their productivity. Consequently, the type of sheep in terms of skin folding in modern breeding should be considered as one of the economically significant criteria. 
A number of scientists (Shumaenko, 2009; Efimova, 2013) note that the efficiency of the livestock industry depends primarily on the degree of feed intake by animals, which make the most of feed to transform it into an increase in production, which is the object of attention of specialists. in further selection (Shumaenko, 2009; Efimova, 2013). Dvalishvili $(2011,2012)$ indicates that the need for feed and its transformation into products is of great importance in the economic component.

Trukhachev et al (2016), when studying various types of anatomical folds and folds on the neck, proved that (i) the development of the skin in merino sheep determines the efficiency of wool production. The greatest effect can be achieved if you pay attention to the required degree and correct type of skin development, (ii) anatomical folds that have an adverse effect on merino sheep are dewlap, large frontal folds, convex body folds, tail and support folds. In the interests of greater adaptation and functional efficiency of merino sheep, it is necessary to eliminate excessive and undesirable types of folds on different parts of the body and to discard such animals. The modern direction of selection in the field of breeding merino sheep provides for the growth of animals of a simple type, a light front type, which best combine adaptability to the environment, high wool productivity and reproductive qualities which completely coincides with the conclusions in this work, which are presented below.

From the data obtained on payment for feed with an increase in live weight and wool, it can be concluded

that:

- animals with an insufficient supply of skin spend on $1 \mathrm{~kg}$ of live weight gain - 6.80 - $9.68 \mathrm{ECU}$, and peers with a satisfactory and increased supply of skin, respectively, 8.00 -10.91 and 9.77-11.87 ECU;

- the average daily gain in live weight in young animals with insufficient skin supply is $1.9-29.6 \%$ higher than in peers of other types;

- the growth of wool in pure fiber on an area of $100 \mathrm{~cm} 2$ is higher in young animals with a satisfactory supply of skin, which surpassed their peers with an insufficient supply of skin by $2.2-8.0$ and an increased supply of skin - by $2.0-7.8 \%$;

- Differentiated determination of feed consumption per 1 kilogram of live weight gain and pure wool gain showed that animals with a satisfactory skin supply for wool gain consume the least amount of feed with average costs for live weight gain.

\section{References}

1) Aboneev, V.V., Rzhepakovsky V.V., Medvedev Yu.B. 1997. Payment for feed by gain in live weight and wool by rams of different genotypes. Materials of the international scientific and practical conference on sheep breeding and goat breeding, dedicated to the 65th anniversary of VNIIOK.-Stavropol, -P. 1.-S. 46-51.

2) Bolotov, N.A. 2011. Payment for feed by gain in live weight and wool. Collection of scientific papers of the Stavropol Research Institute of Livestock and Forage Production / GNU SNIIZhK. 1 (4): 73-78.

3) Dvalishvili V.G. 2011. Efficiency of feed use, fattening and meat qualities of edilbaevskiy and edilbay $\times$ gissar rams. Sheep, goats, woolen business. 4: 60-62.

4) Dvalishvili V.G., Loptev P.E. 2012. Feed use and productivity of Romanov sheep and Edilbai $x$ Romanov crosses. Sheep, goats, woolen business. 3: 58-60.

5) Efimova N.I., Kupriyan A.N. 2013. Fattening and slaughter performance of young stock of the Soviet merino breed and crossbreeds with Australian meat merino. Collection of scientific works of the Stavropol research. - S. 74-77

6) Gogaev O.K. 2018. Postembryonic Development of the Skin of Young Ewes of the Romanov and Tushin Breeds in the Conditions of the Foothill Zone of the North Caucasus. Research Journal of Pharmaceutical, Biological and Chemical Sciences. 9(5): 2335-2346.

7) Gogaev O.K., Ikoeva B.K., Demurova A.R., Ikoeva D.K. 2018. Influence of iodine supplements on indicators of meat productivity of Tushino sheep. Bulletin of the Gorsky State Agrarian University. 55 (3): 60-64.

8) Gogaev O.K, Abaev A.A., Demurova A.R. 2019a. The patterns of linear skeletal growth of the crossbred sheep. Indo American Journal of Pharmaceutical Sciences. 6(4): 8717-8725.

9) Gogaev O.K., Kessaev K.E., Kaloev B.S., Kebekov M.E., Tarchokov T.T. 2016. Formation of skin and hair coat of the romanov sheep in the conditions of the piedmont of the North Caucasus. Asian Journal of Microbiology, Biotechnology and Environmental Sciences. 18(4): 1027-1036. 
10) Gogaev O.K., Yuldashbaev Yu.A., Kebekov M.E., Kairov V.R., Kaloev B.S., Demurova A.R. 2019b. The features of sheep adaptation to their keeping in mountainous conditions. Indo American Journal of Pharmaceutical Sciences. 6(9): 15653-15661.

11) Gogaev O.K., Demurova A.R., Ikoeva B.K., Tokhtieva E.A. 2020a. The effect of different forms of iodine on the blood parameters of sheep. Journal of Livestock Science 11: 40-44.

12) Gogaev O.K., Demurova A.R., Basaeva M.D. 2020b. Trends for the formation of skin and fleece structure in the sheep stock breeding. Journal of Livestock Science 11:116-121

13) Gogaev O.K. et al. 2015. Feeding of young sheep of the Romanov breed in the conditions of the foothill zone of the North Caucasus. Bulletin of the Gorsky State Agrarian University. 52(4): 93-98.

14) Gogaev O.K. et al 2017. Age-related changes in the linear dimensions of the bones of the axial skeleton of sheep. Veterinary medicine of the Kuban. 2: 15-17.

15) Kesaev Kh.E., Gogaev O.K., Bestaeva R.D., Demurova A.R. 2011. Growth and development of some muscles of the axial skeleton of young sheep. Bulletin of the Gorsky State Agrarian University. 48 (2): 68-70.

16) Kesaev H.E., Gogaev O.K., Kusova V.A. 2013. Zootechnical characteristics of sheep of the Grozny breed of the breeding farm "Chervlyonye Buruny" of the Republic of Dagestan. Bulletin of the Gorsky State Agrarian University. Vladikavkaz. 50(1): 134-138.

17) Kesaev H.E., Gogaev O.K., Demurova A.R., Tskhovrebov A.R. 2017. Age-related changes in quantitative and qualitative indicators of meat productivity of sheep of the Tushino breed. Bulletin of the Gorsky State Agrarian University. 54(1): 62-67.

18) Kesaev H.E. et al. 2013. Regularities of weight growth of the muscles of the peripheral skeleton in young sheep. Bulletin of the Gorsky State Agrarian University. 50(4): 53-57.

19) Kesaev H.E. et al. 2015. Growth of young sheep of the Romanov breed in the conditions of the foothill zone of the North Caucasus. Bulletin of the Gorsky State Agrarian University. 52(4): 98-103.

20) Kolosov, Yu.A. 2012. Using the gene pool of domestic and imported merino sheep to improve local merino sheep. Sheep, goats, woolen business. 4: 13-16.

21) Nezhlukchenko T.I., Korbich N.N., Pentilyuk S.I. 2018. The type and folds of the skin of sheep of the Tavrian type of the Askanian fine-wool breed. Actual problems of intensive development of animal husbandry. 21(2): 357-363.

22) Shumaenko S.N. 2009. Efficiency of feeding and meat productivity of rams of different origins. Collection of scientific papers of the Stavropol Research Institute of Animal Breeding and Forage Production. 2(2): 116119.

23) Trukhachev V.I., Moroz V.A., Selionova M.I. 2016. On the types of merino skin folds. Sheep, goats, woolen business. 1: 11-15. 